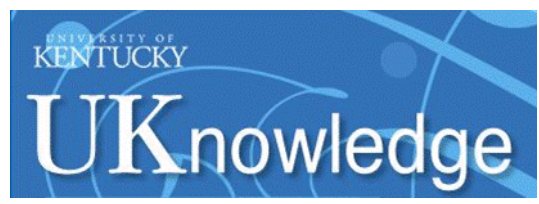

University of Kentucky

UKnowledge

\title{
Designing Resilient and Sustainable Grasslands for a Drier Future: Adaptive Strategies, Functional Traits and Biotic Interactions
}

Florence Volaire

INRA, France

Karim Barkaoui

SupAgro, France

Mark Norton

E. H. Graham Centre for Agricultural Innovation, Australia

Follow this and additional works at: https://uknowledge.uky.edu/igc

Part of the Plant Sciences Commons, and the Soil Science Commons

This document is available at https://uknowledge.uky.edu/igc/22/1/1

The XXII International Grassland Congress (Revitalising Grasslands to Sustain Our Communities) took place in Sydney, Australia from September 15 through September 19, 2013. Proceedings Editors: David L. Michalk, Geoffrey D. Millar, Warwick B. Badgery, and Kim M.

Broadfoot

Publisher: New South Wales Department of Primary Industry, Kite St., Orange New South Wales, Australia

This Event is brought to you for free and open access by the Plant and Soil Sciences at UKnowledge. It has been accepted for inclusion in International Grassland Congress Proceedings by an authorized administrator of UKnowledge. For more information, please contact UKnowledge@lsv.uky.edu. 


\title{
Designing resilient and sustainable grasslands for a drier future: adaptive strategies, functional traits and biotic interactions
}

\author{
Florence Volaire ${ }^{A}$, Karim Barkaoui $^{B}$ and Mark Norton ${ }^{C}$ \\ A Institut National de Recherche Agronomique (INRA), CEFE/CNRS, Montpellier, France \\ B SupAgro -CEFE/CNRS, Montpellier, France \\ ${ }^{C}$ NSW DPI., E. H. Graham Centre for Agricultural Innovation, Wagga Wagga, NSW, Australia \\ Contact email: florence.volaire@cefe.cnrs.fr
}

\begin{abstract}
In many regions of the world, such as Southern Europe and most Mediterranean areas, the frequency and magnitude of droughts and heat waves are expected to increase under global warming and will challenge the sustainability of both native and sown grasslands. To analyze the adaptive strategies of species, genotypes and cultivars, we aim both: (1) to understand the composition and functioning of natural grasslands; and (2) to propose ideotypes of cultivars and optimal composition for mixtures of species/genotypes under water deficit and high temperatures. This review presents a conceptual framework to analyze adaptive responses of perennial herbaceous species, starting from resistance to moderate drought with growth maintenance (dehydration avoidance and tolerance of lamina) to growth cessation and survival of plants under severe stress (dehydration avoidance and tolerance of meristems). The most discriminating functional traits vary according to these contrasting strategies because of a tradeoff between resistance to moderate moisture deficit and survival of intense drought. Consequently it is crucial to measure the traits of interest in the right organs and as a function of soil water use, in order to avoid misleading interpretations of plant responses. Furthermore, collaboration between ecologists, ecophysiologists, and agronomists is required to study the combination of plant strategies in natural grasslands as only this will provide the necessary rules for species and cultivars or ecotypes assemblage. This 'agro-ecological' approach aims to identify and enhance functional complementarity and limit competition within the multi-specific or multi-genotypic material associated in mixtures since using plant biodiversity should contribute to improving grassland resistance and resilience.
\end{abstract}

Keywords: Global warming, adaptation strategies, drought.

\section{Introduction}

Grasslands cover vast areas of the Earth's surface and other than producing forage provide a range of ecosystem services including carbon storage, soil protection and the preservation of biodiversity. In most rain-fed environments, the productivity and sustainability of both native and sown grasslands, depends mainly on temperature and precipitation (Boyer 1982) and will be challenged by predicted warmer climates (I.P.C.C. 2007).

In Southern Europe, a decrease in summer precipitation accompanied by increased temperatures and solar radiation would inevitably lead to more frequent and more intense droughts (Supit et al. 2010; Trnka et al. 2011). Therefore the frequency of widespread mortality events is likely to increase along with long-term pasture degradation associated with the droughts (Ciais et al. 2005). To cope with the negative effects of climate change, short-term adaptations may include changes of species or populations with greater drought tolerance (Olesen et al. 2007). However, breeding efforts in forage plants have taken place mainly in temperate areas and very few cultivars of cool-season perennial grasses which are adapted to severe drought are currently available (Lelièvre and Volaire 2009). It is now known that forage persistence during severe drought is governed by mechanisms different than those conferring resistance to moderate droughts (Milbau et al. 2005; Volaire et al. 2009).

The plant traits conferring relevant adaptive strategies should therefore be defined according to the targeted environments. It is also advocated increasingly to maximise genetic diversity in multi-specific and multigenotypic grasslands as a possible adaptation strategy against climate change (Kreyling et al. 2012). Therefore, this review addresses the following questions: (1) what is a drought tolerant perennial forage genotype? (2) what are the traits associated with the different adaptive strategies to drought and how are these measured reliably? and (3) how do we combine strategies (genotypes) for persistent forage mixtures under drought?

Our objective is to clarify concepts and methods for the study of drought resistance of perennial forage plants since they differ from those intensively studied in major annual crops (Sinclair 2012; Tardieu 2012). We aim to stress the inputs of functional and community ecology applied to native grasslands in order to understand: (1) the nature of trade-offs between plant strategies that should have more implications in the design of breeding programs; and (2) the elaboration of a framework to rationalize the association of genotypes in forage mixtures resilient under both current and future environmental conditions. 


\section{The differences between drought resistance \& drought survival}

\section{Plant growth maintenance versus plant survival: $a$ trade-off}

Drought resistance in crop plants usually defines the ability of species or varieties to grow and yield satisfactorily under periodic drought (May and Milthorpe 1962). This definition is generally assumed without much discussion and is applied to all cultivated species, whether annual of perennial, whether producing grains or biomass and irrespective of the types of drought and environmental constraints. We believe that for perennial herbaceous species, this definition is inadequate and needs modification.

Forage crops and perennial grasslands are expected to produce over many years and their sustainability is associated with yield stability and long-term resilience. Their drought resistance should be therefore analysed over the appropriate time scale and as a function of the magnitude of water deficit experienced by the plants. This drought intensity is estimated as a cumulative index of 'precipitation' minus 'evapotranspiration' accumulated during the dry period (Vicente-Serrano et al. 2012). Measurements of soil water reserve and rooting depth will also provide complementary information on water availability for plants (Vicca et al. 2012).

In the temperate and Mediterranean bioclimatic areas, we propose to make a clear distinction between drought resistance and drought survival, based in particular on recent experiments (Poirier et al. 2012). Under moderate water deficits (cumulative P-ETP lower than around $-300 \mathrm{~mm}$ according to soil depth) and in temperate climates, most genotypes and cultivars of coolseason perennial forage species can be expected to grow. In this case, drought resistance complies with the general definition, i.e. the ability to maintain satisfactory aerial growth and production under a moderate water deficit. Conversely, under severe water deficits (cumulative PETP between -300 and $-600 \mathrm{~mm}$ and according to soil water reserve), plants are expected 'to know when not to grow' (Bielenberg 2011) in order to survive potential lethal conditions.

In these environments, drought resistance combines the ability not to grow during the dry period albeit to survive drought and to regrow when drought is relieved. In this case drought survival is a more suitable term than drought resistance. This issue is exemplified by summer dormancy which confers to genotypes of some grass species the endogenous ability to cease aerial growth and senesce irrespective of the water supply in summer (Volaire and Norton 2006). Summer dormancy has been correlated with superior survival after severe and repeated summer droughts (Norton et al. 2006, 2012), showing that the ability not to grow during the drought period is the most efficient response to maximise drought survival. This 'trade-off' between drought resistance and drought survival can be paralleled with plant responses under winter and low temperatures, when winter dormant plants (no growth) are those most able to survive the winter and regrow in spring (Castonguay et al. 2006).
Drought survival should not therefore, only be associated with marginal cereal crops under extreme environments (Sinclair 2011) or with desiccation tolerant species none of which are of agricultural importance (Farrant and Moore 2011). Drought survival for perennial pasture species is instead, a valuable plant adaptation during part of the plant cycle which may enhance long term persistence and productivity under increasing drought (Lelievre et al. 2011).

\section{Importance of intra-specific variability for drought resistance/survival}

For plant breeders, agronomists and eco-physiologists, the importance of intra-specific variability which is one of the major sources of genetic improvement, is an undisputable fact. In plant ecology working on native plant species, the inter-specific variability of functional traits has been recently challenged by the increasingly recognized importance of intra-specific and ecotypic variability (Albert et al. 2011; Violle et al. 2012). Adaptation of local ecotypes or cultivars to environmental conditions and to drought in particular, has been consistently shown to depend on the origin of the genotypes (Volaire 1995; Volaire and Lelievre 1997; Annicchiarico et al. 2011; Pecetti et al. 2011). In addition, drought resistance and drought survival were associated more with intra-specific than inter-specific variability in two major perennial grasses (Poirier et al. 2012). Consequently, the characterization and comparison of plant stress responses should be necessarily focussed at the level of the genotype or the cultivar, and not only at the 'species' level.

\section{Adaptation strategies to drought - identification and measurement}

\section{Dehydration avoidance and dehydration tolerance}

Plants respond to drought with a combination of mechanistically-linked responses and traits that comprise a particular group of behaviours during periods of water stress characterised into several different 'strategies' (Levitt 1972; Ludlow 1989). Drought escape, the ability of a plant to complete the life cycle before being subjected to serious water stress is relevant mainly for annual species which survive the dry periods as seeds (May and Milthorpe 1962). At the other extreme, desiccation tolerance is only possessed by a rare group of angiosperms termed resurrection or poikilohydric plants (Gaff 1971), which can desiccate to air dryness for long periods, but revive rapidly upon re-watering (Scott 2000). Perennial herbaceous plants combine the more common strategies of both dehydration avoidance and dehydration tolerance (Ludlow 1989). We argue that these strategies have to be analysed in the light of the drought intensity experienced (Fig. 1).

Plant responses resulting in resistance under moderate drought through the maintenance of aerial growth have to avoid and/or tolerate leaf dehydration. Conversely, plant responses resulting in survival under severe drought are mainly associated with both dehydration avoidance and tolerance occurring in meristematic tissues. In some species and genotypes, summer 


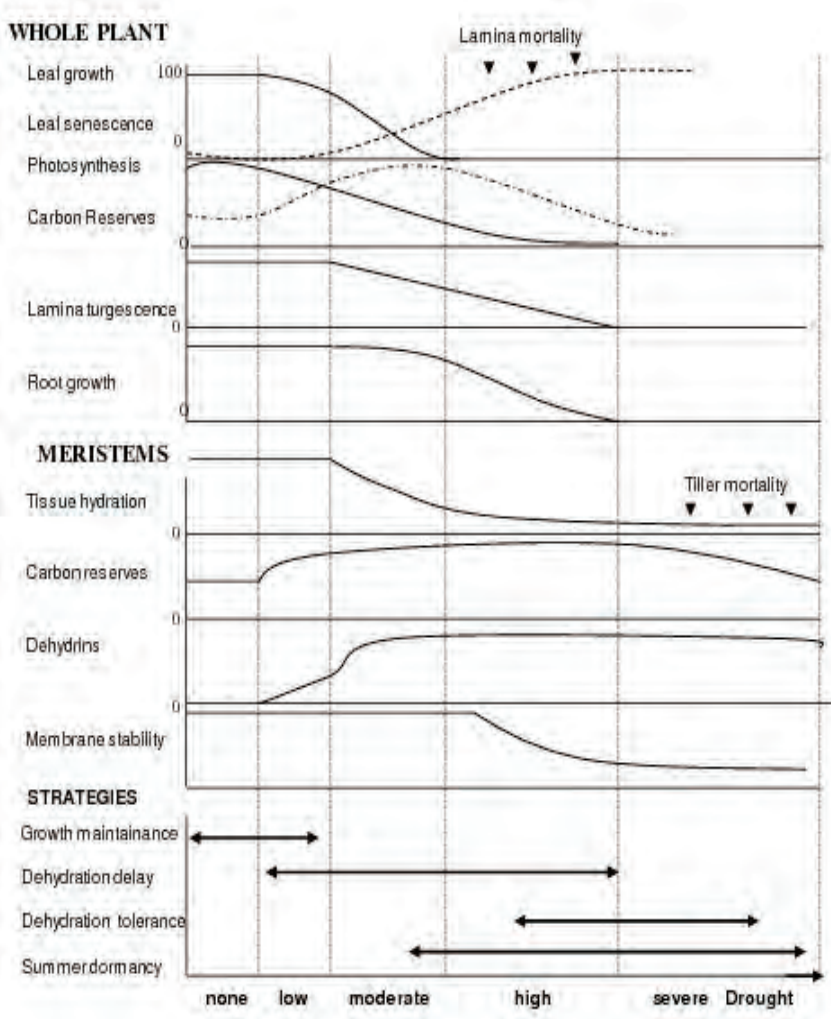

Figure 1. Schematic responses to intensifying drought of perennial grass at the level of whole plant and aerial meristem and resulting ecophysiological strategies (from Volaire et al., 2009). Scales are arbitrary.

dormancy is another combination of strategies which confers efficient survival of meristematic tissues through the dehydration avoidance and tolerance of these organs (Volaire and Norton 2006). Making the distinction between the responses of mature and young tissues seems crucial to analyse properly the strategies of perennial grasses to contrasting drought intensities.

\section{Meristematic tissues can tolerate greater dehydrat- ion than mature tissues in grasses}

In both annual and perennial grasses, stress responses of growing tissues differ substantially from those of expanded mature tissues (Riazi et al. 1985), since basal meristems have been shown to survive more intense water deficits than older tissues (Munns et al. 1979; Barlow et al. 1980; West et al. 1990). Apices are protected from rapid evaporative water loss by their location enclosed within the mature leaf sheaths (Barlow et al. 1980). In addition they are strong sinks within the plants and remain so throughout severe stress resulting in carbohydrate accumulation (Schnyder and Nelson 1989; Volaire et al. 1998a). It is indeed in this most actively growing region of the leaves that the synthesis of fructans and sucrose is the most rapid (Schnyder et al. 1988; Spollen and Nelson 1994). Basal tissues also exhibit the greatest osmotic adjustment relative to other tissues during drought (Munns et al. 1979; Matsuda and Riazi 1981; West et al. 1990). Therefore, basal meristems of grasses can often still regenerate when the adult blades are dead (Van Peer et al. 2004).

\section{Drought resistance: dehydration avoidance and tolerance of lamina}

Traits associated with drought resistance have been much explored and documented in annual grasses particularly in the major cultivated cereals (Ludlow and Muchow 1990; Passioura 1996; Passioura 2006; Sinclair 2011). Although cereals are grown for grain production, a number of identified traits are also relevant for those perennial grasses which are grown for forage (White \& Snow, 2012). Water-use efficiency (WUE) is an integrative variable to measure the aptitude of a plant to grow and produce under moderate water deficit (White and Snow 2012). The enhancement of biomass production under moisture limiting conditions can be achieved primarily by dehydration avoidance through maximising soil water capture while diverting the largest part of the available soil moisture towards stomatal transpiration (Blum 2009). A deep root system with a high density of roots at depth is a major trait to sustain higher yield in water- limited environments (Carrow 1996; Wasson et al. 2012; White and Snow 2012). Maintenance of leaf area, leaf relative water content and photosynthetic capacity are associated with dehydration tolerance of lamina which is based on maintenance of turgor in these tissues by osmotic adjustment (Morgan 1988; Serraj and Sinclair 2002).

\section{Drought survival: dehydration avoidance and toler- ance of meristems}

Traits associated with drought survival have been much less explored (Volaire et al. 2009) although recent efforts to explore the physiological mechanisms of droughtinduced mortality have been made in trees and show the relative importance of carbon starvation and hydraulic failure in these model plants (Sala et al. 2010; McDowell 2011). In perennial grasses, drought survival should be measured after rehydration following the drought period, using values such as the percentage of plant survival and the recovery biomass in the subsequent seasons (Volaire et al. 1998b; Milbau et al. 2005; Poirier et al. 2012).

As plant meristems (including root apices) are the key surviving organs, adaptive responses contribute to the dehydration avoidance of theses tissues, through the crucial maintenance of a minimum water supply (McWilliam and Kramer 1968; Karcher et al. 2008) even at low water potential (Volaire and Lelievre 2001). Dehydration avoidance is also mediated through leaf senescence and leaf shedding which play a major role in reducing total plant water losses and therefore in the survival of many species especially under drought (Gepstein 2004; Munne Bosch and Alegre 2004). Dehydration tolerance of meristems has been shown to be potentially very efficient in adapted genotypes since high concentrations of fructans and dehydrins contribute to osmoregulation and membrane stabilisation of these tissues (Hincha et al. 2000; Hincha et al. 2002). Indeed, high carbohydrate reserves are associated with superior plant resilience and recovery after severe drought, with a strong interaction with defoliation intensity (Boschma et al. 2003). 
Summer dormancy induces (even under irrigation) the cessation or reduction of aerial growth, various degrees of foliage senescence and a dehydration tolerance of meristems that remain viable under very severe water deficits (Volaire and Norton 2006). It is worth underlining again that the interpretation of drought resistance versus drought survival should rest on the responses of the right organs. To interpret low leaf water potential or high foliage senescence as responses associated with drought sensitivity and poor adaptation may be correct if drought resistance is targeted but highly misleading if drought survival is the focus. Genotypes that survive best can reach very low leaf water potentials such as -5 to $-7 \mathrm{MPa}$ in the remaining meristems (Norton et al. 2006; Poirier et al. 2012) even though their foliage senescence is almost complete under severe drought. The measurements of dehydration tolerance must therefore be focused on the correct organs, i.e. the meristems.

\section{Methodological aspects in the measurement of plant responses and strategies}

In order to understand the balance between the different strategies and their values to plants, it is essential to measure both environmental stress and the plants' responses under experimental droughts which should be similar in intensity to the stresses that occur naturally (Bray 1993; Jones 2007). Moreover, it is crucial to ensure that the 'stress' treatments are truly comparable between tested genotypes. In particular, differences in water use due to differences in leaf area or root depth can strongly interfere with drought resistance/survival (Jones 2007). It is worth stressing that the interaction with plant size complicates the interpretation of performance differences between genotypes since the depletion of soil water is a function of leaf area and total transpiration and not necessarily of any physiological or morphological acclimation (Poorter et al. 2012). To avoid these confounding effects, the best approach should be to model the responses of each genotype as a function of its specific kinetics of soil available water and to avoid using a time scale (such as number of days) as these are mostly irrelevant when comparing contrasting genotypes under progressive drought.

To disentangle the different strategies, we believe that the experimental conditions should be chosen carefully. The analysis of dehydration delay should be carried out in conditions allowing the full expression of root length and density such as long tubes (to measure root traits and water uptake in individual plants) or deep soils (to measure water uptake in dense swards). Conversely, dehydration tolerance should be tested in short pots to eliminate the effect of differences of root depth (the largest component of dehydration delay) on water availability (Volaire and Lelievre 2001; Pérez-Ramos et al. 2013). Dehydration tolerance can be tested by measuring plant survival after rehydration once a predetermined soil moisture is reached by all genotypes (Pérez-Ramos et al. 2013) or after successive rehydration with calculation of the soil moisture associated with $50 \%$ plant mortality (Volaire et al. 2005).

The measurement of summer dormancy is based on scoring plant growth (1) under summer irrigation or (2) regrowth after a mid-summer storm (Oram 1983), under the correct inductive day-length and temperatures and after vernalisation during the previous winter (Ofir and Kerem 1982; Norton et al. 2008). Using the right methodologies, a functional typology of plant material according to their adaptive strategies can be defined to predict plant responses under a range of potential drought intensities (Volaire et al. 2009b).

\section{How to combine plant strategies to develop resilient forage mixtures under drought?}

The contribution of community ecology for the design of multi-species grasslands

Establishing persistent and multi-specific grasslands should become a major goal to ensure sustainable agricultural production and ecosystem services (=ecosystem stability). Ecosystem stability is a multi-faceted concept and it is associated in particular with both ecosystem resistance, which refers to the maintenance of productivity despite changes in the environment, and ecosystem resilience, which refers to the recovery of ecosystem functions and productivity after a temporal alteration due to changes in the environment. While grassland resistance and productivity could be reasonably expected under moderate levels of environmental stress, persistence and resilience of multi-annual productivity is a target for grasslands under severe or extreme levels of environmental stress (Figure 2).

In natural grassland ecosystems, evolution has led to diverse plant adaptive strategies combining different functions at the community level. Following the description stage of these strategies using relevant plant traits as suggested above, agro-ecology then seeks to define how they should be associated together in order to optimize the ecosystem services provided by multi- specific grasslands. In the following section, concepts of plant community ecology underlying how species assemble in natural grasslands are assumed to provide a suitable framework to define relevant associations of forage cultivars with the most efficient biotic interactions under stressful environments.

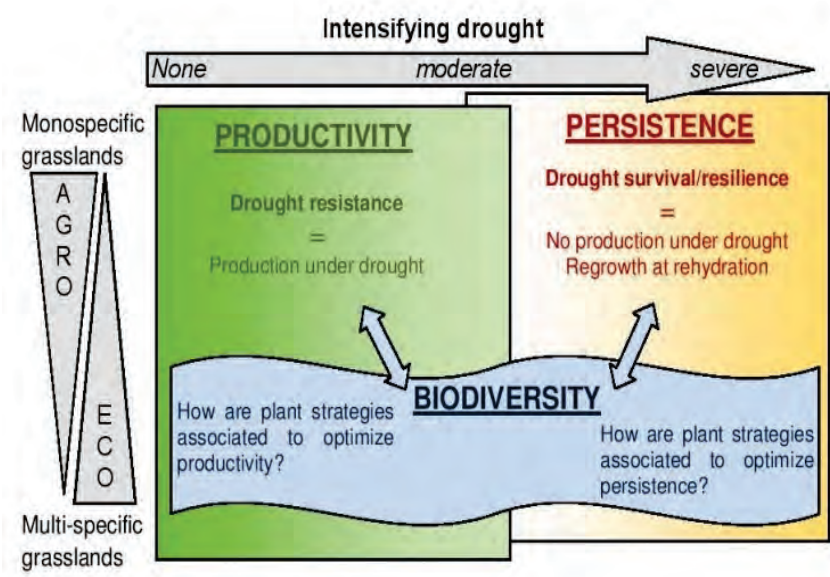

Figure 2. A major focus of grassland agro-ecology is to design sustainable mono- and multi-specific grasslands with targeted functions (productivity, biodiversity and perenniality) under intensifying droughts. 


\section{Expected effect of biodiversity on ecosystem functioning}

Biodiversity, whether at the level of genotypes, species, or communities strongly affects ecosystem functioning over time (Fridley 2001; Hooper et al. 2005). Importantly for the conception of forage mixtures, a positive relationship between species richness and productivity is expected through plant overyielding, i.e greater plant biomass production in species mixtures compared with monocultures (Vandermeer 1989). However empirical results obtained for sown and natural grasslands are still controversial since some studies show strong positive effects of species diversity on productivity (Tilman et al. 1996; Tilman et al. 1997; Hector et al. 1999; Tilman et al. 2001) whereas others reach opposite conclusions (Garnier et al. 1997; Huston 1997). Nonetheless, a consensual view is that the increase in productivity associated with intercropping results not from the total number of species, but from the unique role of a few dominant species with adaptive traits and specific properties (Garnier et al. 2004; Mokany et al. 2008).

Moreover, biodiversity should also act as a safeguard of ecosystem functioning, leading to more stabilized ecosystem functions in response to environmental fluctuations when species diversity increases (Grime 1997; Ives and Carpenter 2007; Campbell et al. 2011). It was shown that the larger the number of species in a plant community but with a range of environmental sensitivities, the greater the probability that at least some of these species will survive changes in the environment and maintain the functions of the ecosystem (Diaz and Cabido 2001). Especially for water-limited grasslands, primary productivity in more diverse communities is expected to be more resistant to, and recover more fully from a major drought (Tilman and Downing 1994; Grime 1997; van Ruijven and Berendse 2010).

The positive role of species diversity in ecosystem functioning is driven by the following mechanisms. Firstly, species niche differentiation leads to different levels of functional complementarity among plants, reducing plant competition compared to that in a monoculture. Secondly, positive interactions or facilitation, occurs when one species enhances the plant performance of another because of beneficial effects on local resource availability (Callaway 1995). Mechanisms related to the properties of dominant species and those related to species diversity may be involved simultaneously even though their relative importance is unclear (Huston 1997). Properties of dominant species may have an overall effect of leading ecosystem functioning over short-term periods (Grime 1998), while functional complementarity and/or facilitation may enhance the persistence of ecosystem functions over the long-term, buffering the overall environmental fluctuations (Allan et al. 2011).

\section{Minimizing plant competition: searching for high functional complementarity among species}

Interspecific competition is a key process in multispecific communities that needs to be limited since it may alter plant performance and ecosystem functions. According to several ecological models of plant coexistence such as the limiting similarity hypothesis (Macarthur and Levins 1967; Chesson 2000), this is achieved by enhancing functional complementarity for resource use among plants through the association of species with different functional strategies reflecting their resource economy and plant biomass investment (Stubbs and Wilson 2004). The higher the functional complementarity, the less is the competition among plants.

Temporal and spatial partitioning of resources (Hooper 1998) are major factors that structure the coexistence of plant species, as was recently demonstrated in Mediterranean communities (Penuelas et al. 2011). Using a trait-based approach to plant competition (Navas and Violle 2009), functional complementarity among species can be comprehended in terms of differences between relevant plant traits related to resource acquisition/conservation and plant biomass allocation, including plant architectural or phenological traits (Weiher et al. 2011). For example, contrasting plant height and aboveground bio-volume, which reflects growth potential, as well as specific leaf area that reflects light interception efficiency, have been associated with different levels of light requirement (Gross et al. 2007; Violle et al. 2009; Mason et al. 2013). Likewise, contrasting species rooting depth potential and fine root distribution have been argued to partition belowground available resources (Verheyen et al. 2008; Yang et al. 2011). Furthermore, contrasting flowering date, a relevant marker of plant biomass allocation establishment and therefore of resource use dynamics, may segregate the periods during which resources are required by the different species (Catorci et al. 2012). Moreover, asynchrony in demographic processes within species-rich communities has been suggested as a major mechanism guaranteeing ecosystem stability through compensation effects among species over time (Hector et al. 2010). However, many, if not most of the plant competition studies have been conducted for resources such as light or soil nutrients. Relevant traits related to soil water use have not yet been precisely identified and tested. Associating species with different rooting depth and contrasting adaptive strategies to drought (resistance, avoidance and survival) should be a high research priority given the predicted changes of future climates.

\section{The dream of facilitation-different species helping one another}

Under facilitation, plant performance may be enhanced by neighboring plants through their favorable modification of the local environment. Facilitation is distinct from functional complementarity since it involves underlying mechanisms other than species niche differentiation (Bruno et al. 2003; Brooker et al. 2008). Facilitation (Callaway 1995) results from a favorable alteration of resource availability (e.g. soil nutrients, soil water, light), protection from wind and stressful temper-atures, or a beneficial modification of biotic interactions with other species or trophic levels (e.g. herbivores, pollinisators, mycorrhizae). 
A well-known facilitative mechanism among plants is the nutrient enrichment by legumes which has been a major functional mechanism addressed in grassland biodiversity-productivity experiments (Mulder et al. 2002; Spehn et al. 2002). In natural communities, evidence for facilitation also came from high altitude areas or from deserts, where large nurse plant species often enhance the establishment of seedlings and plant growth of other species by alleviating thermal and water stresses (Butterfield et al. 2010; Schob et al. 2012).

While a combination of plant traits has been identified for the ability to form a symbiotic association with nitrogen-fixing bacteria and therefore to enhance nutrient enrichment, specific plant traits are not clear for other facilitation mechanisms such as the "nurse" effect. For the water resource, water sharing via hydraulic lift has been identified as a promising facilitative mechanism for grass-shrub mixtures (Caldwell et al. 1998; Prieto et al. 2012) but remains to be demonstrated for grasslands. Moreover, the relevancy of such positive interaction in the conception of water-limited agricultural system remains questionable since facilitation may dramatically decrease with increasing aridity (Rietkerk et al. 2004; Kefi et al. 2007).

\section{Community assembly rules matter for persistence of grasslands!}

The conception of persistent forage mixtures should be supported by the identification of rules governing community assembly (Keddy 1992; Grime 2006; Weiher et al. 2011). An important point is the strong interdependency of local environmental conditions and plant interaction processes (Brooker and Kikividze 2008; Spasojevic and Suding 2012). Given the major role played by abiotic factors in regulating ecosystem functioning (Ciais et al. 2005; Huston 2012), mechanisms underlying plant interaction processes, and therefore linking species diversity to ecosystem functioning, strongly depend on the environment (Hooper et al. 2005). For instance, the outcome of plant interaction, i.e the net result of competition and facilitation processes, varies along environmental gradients, with facilitation becoming more important in more stressful habitats. Hence, if facilitation among species is a potential means by which plant performance may be enhanced, it should be most apparent under severe stress or in resource-poor environments (Callaway et al. 2002; Maestre et al. 2009; Armas et al. 2011). Likewise, functional complementarity should occur more commonly under moderate environmental stress or in resource-rich environments where competition is important and where resource partitioning is possible (Weiher and Keddy 1995; Gross et al. 2007). Thus, management of plant interactions in promoting sward species coexistence across a range of environments must consider the co-variation of the effects of biotic interactions and abiotic factors on plant performance. Consequently, no single ideal pattern of plant diversity can be defined.

To face an increasing frequency of droughts, the challenge of grassland agro-ecology is to design and test a range of forage mixtures based on sound community assembly rules for various types of environments where the short-term productivity and long term persistence are targeted (Figure 2). Further research is clearly needed, in particular in environments subjected to increasingly frequent drought and heat waves, to address the following key-questions: (1) to which extent are the assembly rules and biotic interactions identified in natural communities with low productivity, valid for the conception of multi-specific grasslands based on cultivars selected for their high productivity in monocultures and therefore with high competitiveness for resources?; and (2) how to ensure the long-term performance of a community by combining high functional complementarity with species or genotypes of contrasting strategies exhibiting various trade-offs between growth and stress resistance/survival (drought escape, avoidance, dormancy...)? Both experimental and modeling research is needed and should aim to define the most efficient assembly rules of plant material for various types of environments.

\section{Conclusions}

To cope with the increase of drought occurrence impacting forage production worldwide, we point out two main challenges for plant breeding and agro-ecology research. The first challenge is to design ideotypes of forage plants to ensure long-term sustainable production, either to maintain plant growth under moderate drought as expected in temperate areas or to survive severe drought and recover actively afterwards, as expected in drier areas such as the Mediterranean regions. In this last case, expected to occur at a larger scale, the lack of adapted, commercially available cultivars contrasts starkly with the hundreds of perennial grasses and legume cultivars registered for temperate areas throughout the World (Lelièvre and Volaire 2009). It is therefore urgently required to select new plant material, incorporating traits associated with improved long-term survival and persistence according to defined levels of drought (Blum 1996) and then to ensure that sufficient seed of these cultivars is commercially available.

The second challenge is to develop the conception and agronomic practices for forage mixtures which ensure that species diversity would buffer environmental fluctuations and enhance resistance and resilience of grasslands. To this end, a close collaboration between agronomists and plant ecologists should promote the applications of the concepts of community ecology to the design of multi-specific grasslands adapted to present and future environments.

\section{Acknowledgments}

This work was funded in part by the French ANR program O2LA (09-STRA-09).

\section{References}

Albert CH, Grassein F, Schurr FM, Vieilledent G, Violle C (2011) When and how should intraspecific variability be considered in trait-based plant ecology? Perspectives in Plant Ecology Evolution and Systematics 13, 217-225.

Allan E, Weisser W, Weigelt A, Roscher C, Fischer M, Hillebrand H (2011) More diverse plant communities have 
higher functioning over time due to turnover in complementary dominant species. Proceedings of the National Academy of Sciences 108, 17034-17039.

Annicchiarico P, Pecetti L, Bouzerzour H, Kallida R, Khedim A, Porqueddu C, Simoes NM, Volaire F, Lelièvre F (2011) Adaptation of contrasting cocksfoot plant types to agricultural environments across the Mediterranean basin. Environmental and Experimental Botany 74, 82-89.

Armas C, Rodriguez-Echeverria S, Pugnaire FI (2011) A field test of the stress-gradient hypothesis along an aridity gradient. Journal of Vegetation Science 22, 818-827.

Barlow EWR, Munns RE, Brady DJ (1980) Drought responses of apical meristems. In 'Adaptation of Plants to Water and High Temperature Stress.' (Eds NC Turner, PJ Kramer.) pp. 191-205. (John Wiley \& Sons: New York, USA)

Bielenberg DG (2011) Knowing when not to grow. New Phytologist 189, 3-5.

Blum A (1996) Crop responses to drought and the interpretation of adaptation. Plant Growth Regulation 20, 135-148.

Blum A (2009) Effective use of water (EUW) and not wateruse efficiency (WUE) is the target of crop yield improvement under drought stress. Field Crops Research 112, 119-123.

Boschma SP, Hill MJ, Scott JM, Rapp GG (2003) The response to moisture and defoliation stresses, and traits for resilience of perennial grasses on the Northern Tablelands of New South Wales, Australia. Australian Journal of Agricultural Research 54, 903-916.

Boyer JS (1982) Plant productivity and environment. Science 218, 443-448.

Bray EA (1993) Molecular responses to water deficit. Plant Physiology 103, 11-16.

Brooker RW, Kikividze Z (2008) Importance: an overlooked concept in plant interaction research. Journal of Ecology 96, 703-708.

Brooker RW, Maestre FT, Callaway RM, Lortie CL, Cavieres LA, Kunstler G, Liancourt P, Tielborger K, Travis JMJ, Anthelme F, Armas C, Coll L, Corcket E, Delzon S, Forey E, Kikvidze Z, Olofsson J, Pugnaire F, Quiroz CL, Saccone P, Schiffers K, Seifan M, Touzard B, Michalet R (2008) Facilitation in plant communities: the past, the present, and the future. Journal of Ecology 96, 18-34.

Bruno, JF Stachowicz JJ, Bertness MD (2003) Inclusion of facilitation into ecological theory. Trends in Ecology \& Evolution 18, 119-125.

Butterfield BJ, Betancourt JL, Turner RM, Briggs JM (2010) Facilitation drives 65 years of vegetation change in the Sonoran Desert. Ecology 91, 1132-1139.

Caldwell MM, Dawson TE, Richards JH (1998) Hydraulic lift: Consequences of water efflux from the roots of plants. Oecologia 113, 151-161.

Callaway, RM (1995) Positive interactions among plants. Botanical Review 61, 306-349.

Callaway RM, Brooker RW, Choler P, Kikvidze Z, Lortie CJ, Michalet R, Paolini L, Pugnaire FI, Newingham B, Aschehoug ET, Armas C, Kikodze D, Cook BJ (2002) Positive interactions among alpine plants increase with stress. Nature 417, 844-848.

Campbell V, Murphy G, Romanuk TN (2011) Experimental design and the outcome and interpretation of diversitystability relations. Oikos 120, 399-408.

Carrow RN (1996) Drought avoidance characteristics of diverse tall fescue cultivars. Crop Science 36, 371-377.

Castonguay Y, Laberge S, Brummer EC, Volenec JJ (2006) Alfalfa winter hardiness: A research retrospective and integrated perspective. In 'Advances in Agronomy, Vol 90.' (Ed. DL Sparks.) Vol. 90 pp. 203-265. (Elsevier Academic Press Inc: San Diego)
Catorci A, Cesaretti S, Gatti R, Tardella FM (2012) Traitrelated flowering patterns in submediterranean mountain meadows. Plant Ecology 213, 1315-1328.

Chesson P (2000) Mechanisms of maintenance of species diversity. Annual Review of Ecology and Systematics 31, 343-366

Ciais P, Reichstein M, Viovy N, Granier A, Ogee J, Allard V, Aubinet M, Buchmann N, Bernhofer C, Carrara A, Chevallier F, De Noblet N, Friend AD, Friedlingstein P, Grunwald T, Heinesch B, Keronen P, Knohl A, Krinner G, Loustau D, Manca G, Matteucci G, Miglietta F, Ourcival JM, Papale D, Pilegaard K, Rambal S, Seufert G, Soussana JF, Sanz MJ, Schulze ED, Vesala T, Valentini R (2005) Europe-wide reduction in primary productivity caused by the heat and drought in 2003. Nature 437, 529-533.

Diaz S, Cabido M (2001) Vive la difference: plant functional diversity matters to ecosystem processes. Trends in Ecology \& Evolution 16, 646-655.

Farrant JM, Moore JP (2011) Programming desiccationtolerance: from plants to seeds to resurrection plants. Current Opinion in Plant Biology 14, 340-345.

Fridley JD (2001) The influence of species diversity on ecosystem productivity: how, where, and why? Oikos 93, 514-526.

Gaff D (1971) Desiccation tolerant flowering plants in Southern Africa. Science 174, 1033-1034.

Garnier E, Cortez J, Billes G, Navas ML, Roumet C, Debussche M, Laurent G, Blanchard A, Aubry D, Bellmann A, Neill C, Toussaint JP (2004) Plant functional markers capture ecosystem properties during secondary succession. Ecology 85, 2630-2637.

Garnier E, Navas ML, Austin MP, Lilley JM, Gifford RM (1997) A problem for biodiversity-productivity studies: how to compare the productivity of multispecific plant mixtures to that of monocultures? Acta OecologicaInternational Journal of Ecology 18, 657-670.

Gepstein S (2004) Leaf senescence - not just a 'wear and tear' phenomenon. Genome Biology 5, 212. 10.1186/gb-20045-3-212

Grime JP (1997) Ecology - Biodiversity and ecosystem function: The debate deepens. Science 277, 1260-1261.

Grime JP (1998) Benefits of plant diversity to ecosystems: immediate, filter and founder effects. Journal of Ecology 86, 902-910.

Grime JP (2006) Trait convergence and trait divergence in herbaceous plant communities: Mechanisms and consequences. Journal of Vegetation Science 17, 255-260.

Gross N, Suding KN, Lavorel S, Roumet C (2007) Complementarity as a mechanism of coexistence between functional groups of grasses. Journal of Ecology 95, 12961305.

Hector A, Hautier Y, Saner P, Wacker L, Bagchi R, Joshi J, Scherer-Lorenzen M, Spehn EM, Bazeley-White E, Weilenmann M, Caldeira MC, Dimitrakopoulos PG, Finn JA, Huss-Danell K, Jumpponen A, Mulder CPH, Palmborg C, Pereira JS, Siamantziouras ASD, Terry AC, Troumbis AY, Schmid B, Loreau M (2010) General stabilizing effects of plant diversity on grassland productivity through population asynchrony and overyielding. Ecology 91, 2213-2220.

Hector A, Schmid B, Beierkuhnlein C, Caldeira MC, Diemer M, Dimitrakopoulos PG, Finn JA, Freitas H, Giller PS, Good J, Harris R, Hogberg P, Huss-Danell K, Joshi J, Jumpponen A, Korner C, Leadley PW, Loreau M, Minns A, Mulder CPH, O'Donovan G, Otway SJ, Pereira JS, Prinz A, Read DJ, Scherer-Lorenzen M, Schulze ED, Siamantziouras ASD, Spehn EM, Terry AC, Troumbis AY, Woodward FI, Yachi S, Lawton JH (1999) Plant diversity and productivity experiments in European 
grasslands. Science 286, 1123-1127.

Hincha DK, Hellwege EM, Heyer AG, Crowe JH (2000) Plant fructans stabilize phosphatidylcholine liposomes during freeze-drying. European Journal of Biochemistry 267, 535-540.

Hincha DK, Zuther E, Hellwege EM, Heyer AG (2002) Specific effects of fructo- and gluco-oligosaccharides in the preservation of liposomes during drying. Glycobiology 12, $103-110$

Hooper DU (1998) The role of complementarity and competition in ecosystem responses to variation in plant diversity. Ecology 79, 704-719.

Hooper, DU, Chapin FS, Ewel JJ, Hector A, Inchausti P, Lavorel S, Lawton JH, Lodge DM, Loreau M, Naeem S, Schmid B, Setala H, Symstad AJ, Vandermeer J, Wardle DA (2005) Effects of biodiversity on ecosystem functioning: A consensus of current knowledge. Ecological Monographs 75, 3-35.

Huston MA (1997) Hidden treatments in ecological experiments: Re-evaluating the ecosystem function of biodiversity. Oecologia 110, 449-460.

Huston MA (2012) Precipitation, soils, NPP, and biodiversity: resurrection of Albrecht's curve. Ecological Monographs 82, 277-296.

I.P.C.C. (2007) International Panel of Climatic changes. Fourth assessment report (AR4). New-York.

Ives AR, Carpenter SR (2007) Stability and diversity of ecosystems. Science 317, 58-62.

Jones HG (2007) Monitoring plant and soil water status: established and novel methods revisited and their relevance to studies of drought tolerance. Journal of Experimental Botany 58, 119-130.

Karcher DE, Richardson MD, Hignight K, Rush D (2008) Drought tolerance of tall fescue populations selected for high root/shoot ratios and summer survival. Crop Science 48, 771-777.

Keddy PA (1992) Assembly and response rules - two goals for predictive community ecology. Journal of Vegetation Science 3, 157-164.

Kefi S, Rietkerk M, Alados CL, Pueyo Y, Papanastasis VP, ElAich A, de Ruiter PC (2007) Spatial vegetation patterns and imminent desertification in Mediterranean arid ecosystems. Nature 449, 213-U5.

Kreyling J, Thiel D, Simmnacher K, Willner E, Jentsch A, Beierkuhnlein C (2012) Geographic origin and past climatic experience influence the response to late spring frost in four common grass species in central Europe. Ecography 35, 268-275.

Lelièvre F, Seddaiu G, Ledda L, Porqueddu C, Volaire F (2011) Water use efficiency and drought survival in Mediterranean perennial forage grasses. Field Crops Research 121, 333-342.

Lelièvre F, Volaire F (2009) Current and potential development of perennial grasses in rainfed Mediterranean farming systems. Crop Science 49, 2371-2378.

Levitt JV (Ed.) (1972) 'Responses of Plants to Environmental Stress.' (Academic Press: New-York)

Ludlow MM (1989) Strategies of response to water stress. In 'Structural and functional responses to environmental stresses: water shortage.' (Eds KH Kreeb, H Richter, TM Hinckley.) pp. 269-281. (SPB Academic Publishing BV: The Hague)

Ludlow MM, Muchow RC (1990) A critical evaluation of traits for improving crop yields in water-limited environments. Advances-in-Agronomy. 43, 107-153.

Macarthur R, Levins R (1967) Limiting similarity convergence and divergence of coexisting species. American Naturalist 101, 377-385

Maestre FT, Callaway RM, Valladares F, Lortie CJ (2009)
Refining the stress-gradient hypothesis for competition and facilitation in plant communities. Journal of Ecology 97, 199-205.

Mason NWH, Pipenbaher N, Skornik S, Kaligaric M (2013) Does complementarity in leaf phenology and inclination promote co-existence in a species-rich meadow? Evidence from functional groups. Journal of Vegetation Science 24, 94-100.

Matsuda K, Riazi A (1981) Stress-induced osmotic adjustment in growing regions of barley leaves. Plant Physiology 68, 571-576.

May LH, Milthorpe FL (1962) Drought resistance in crop plants. Field Crop Abstracts 15, 171-179

McDowell NG (2011) Mechanisms linking drought, hydraulics, carbon metabolism, and vegetation mortality. Plant Physiology 155, 1051-1059.

McWilliam JR, Kramer PJ (1968) The nature of the perennial response in Mediterranean grasses. 1. Water relations and summer survival in Phalaris. Australian Journal Agricultural Research 19, 381-395.

Milbau A, Scheerlinck L, Reheul D, De Cauwer B, Nijs I (2005) Ecophysiological and morphological parameters related to survival in grass species exposed to an extreme climatic event. Physiologia Plantarum 125, 500-512.

Mokany K, Ash J, Roxburgh S (2008) Functional identity is more important than diversity in influencing ecosystem processes in a temperate native grassland. Journal of Ecology 96, 884-893.

Morgan JM (1988) Physiological traits for drought resistance. Drought resistance in cereals $\mathrm{CAB}$ International, Wallingford, UK,

Mulder, CPH, Jumpponen, A, Hogberg, P, Huss-Danell, K (2002) How plant diversity and legumes affect nitrogen dynamics in experimental grassland communities. Oecologia 133, 412-421.

Munne Bosch S., Alegre L. (2004) Die and let live: leaf senescence contributes to plant survival under drought stress. Functional-Plant-Biology. 31, 203-216.

Munns R, Brady CJ, Barlow EWR (1979) Solute accumulation in the apex and leaves of wheat during water-stress. Australian Journal of Plant Physiology 6, 379-389.

Navas ML, Violle C (2009) Plant traits related to competition: how do they shape the functional diversity of communities? Community Ecology 10, 131-137.

Norton MR, Lelievre F, Fukai S, Volaire F (2008) Measurement of summer dormancy in temperate perennial pasture grasses. Australian Journal Agricultural Research 59, (6), 498-509.

Norton MR, Lelievre F, Volaire F (2006) Summer dormancy in Dactylis glomerata L., the influence of season of sowing and a simulated mid-summer storm on two contrasting cultivars. Australian Journal of Agricultural Research 57, 1267-1277.

Norton MR, Lelievre F, Volaire F (2012) Summer dormancy in Phalaris aquatica L., the influence of season of sowing and summer moisture regime on two contrasting cultivars. Journal of Agronomy and Crop Science 198, 1-13.

Ofir M, Kerem D (1982) The effects of temperature and photoperiod on the onset of summer dormancy in Poa bulbosa L. Annals of Botany 50, 259-264.

Olesen JE, Carter TR, Diaz-Ambrona CH, Fronzek S, Heidmann T, Hickler T, Holt T, Minguez MI, Morales P, Palutikof JP, Quemada M, Ruiz-Ramos M, Rubaek GH, Sau F, Smith B, Sykes MT (2007) Uncertainties in projected impacts of climate change on European agriculture and terrestrial ecosystems based on scenarios from regional climate models. Climatic Change 81, 123143.

Oram RN (1983) Ecotypic differentiation for dormancy levels 
in oversummering buds of Phalaris aquatica L. Botanical Gazette 144, 544-551.

Passioura J. B (1996) Drought and drought tolerance. Plant Growth Regulation, 20, 79-83.

Passioura J (2006) Increasing crop productivity when water is scarce - from breeding to field management. Agricultural Water Management 80, 176-196.

Pecetti L, Annicchiarico P, Abdelguerfi A, Kallida R, Mefti M, Porqueddu C, Simoes NM, Volaire F, Lelievre F (2011) Response of Mediterranean tall fescue cultivars to contrasting agricultural environments and implications for Selection. Journal of Agronomy and Crop Science 197, 1220.

Penuelas J, Terradas J, Lloret F (2011) Solving the conundrum of plant species coexistence: water in space and time matters most. New Phytologist 189, 5-8.

Pérez-Ramos IM, Volaire F, Fattet M, Blanchard A, Roumet C (2013) Tradeoffs between functional strategies for resource-use and drought-survival in Mediterranean rangeland species. Environmental and Experimental Botany 87, 126-136.

Poirier M, Durand JL, Volaire F (2012) Persistence and production of perennial grasses under water deficits and extreme temperatures: importance of intraspecific vs. interspecific variability. Global Change Biology 18, 36323646.

Poorter H, Fiorani F, Stitt M, Schurr U, Finck A, Gibon Y, Usadel B, Munns R, Atkin OK, Tardieu F, Pons TL (2012) The art of growing plants for experimental purposes: a practical guide for the plant biologist. Functional Plant Biology 39, 821-838.

Prieto I, Armas C, Pugnaire FI (2012) Water release through plant roots: new insights into its consequences at the plant and ecosystem level. New Phytologist 193, 830-841.

Riazi A, Matsuda K, Arslan A (1985) Water-stress induced changes in concentrations of proline and other solutes in growing regions of young barley leaves. Journal of Experimental Botany 36, 1716-1725.

Rietkerk M, Dekker SC, de Ruiter PC, van de Koppel J (2004) Self-organized patchiness and catastrophic shifts in ecosystems. Science 305, 1926-1929.

Sala A, Piper F, Hoch G (2010) Physiological mechanisms of drought-induced tree mortality are far from being resolved. New Phytologist 186, 274-281.

Schnyder H, Nelson CJ (1989) Growth rates and assimilate partitioning in the elongation zone of tall fescuue leaf blades at high and low irradiance. Plant Physiology 90, 1201-1206.

Schnyder H, Nelson CJ, Spollen WG (1988) Diurnal growth of tall fescue leaf blades. 2. Dry matter partitioning and carbohydrate metabolism in the elongation zone and adjacent expanded tissue. Plant Physiology 86, 1077-1083.

Schob C, Butterfield BJ, Pugnaire FI (2012) Foundation species influence trait-based community assembly. New Phytologist 196, 824-834.

Scott P (2000) Resurrection plants and the secrets of eternal leaf. Annals of Botany 85, 159-166.

Serraj R, Sinclair TR (2002) Osmolyte accumulation: can it really help increase crop yield under drought conditions? Plant Cell and Environment 25, 333-341.

Sinclair TR (2011) Challenges in breeding for yield increase for drought. Trends in Plant Science 16, 289-293.

Sinclair TR (2012) Is transpiration efficiency a viable plant trait in breeding for crop improvement? Functional Plant Biology 39, 359-365.

Spasojevic MJ, Suding KN (2012) Inferring community assembly mechanisms from functional diversity patterns: the importance of multiple assembly processes. Journal of Ecology 100, 652-661.
Spehn EM, Scherer-Lorenzen M, Schmid B, Hector A, Caldeira MC, Dimitrakopoulos PG, Finn JA, Jumpponen A, O'Donnovan G, Pereira JS, Schulze ED, Troumbis AY, Korner C (2002) The role of legumes as a component of biodiversity in a cross-European study of grassland biomass nitrogen. Oikos 98, 205-218.

Spollen WG, Nelson CJ (1994) Response of fructan to water deficit in growing leaves of tall fescue. Plant Physiology 106, 329-336.

Stubbs WJ, Wilson JB (2004) Evidence for limiting similarity in a sand dune community. Journal of Ecology 92, 557567.

Supit I, van Diepen CA, de Wit AJW, Kabat P, Baruth B, Ludwig F (2010) Recent changes in the climatic yield potential of various crops in Europe. Agricultural Systems 103, 683-694.

Tardieu F (2012) Any trait or trait-related allele can confer drought tolerance: just design the right drought scenario. Journal of Experimental Botany 63, 25-31.

Tilman D, Downing JA (1994) Biodiversity and stability in grasslands. Nature 367, 363-365.

Tilman D, Knops J, Wedin D, Reich P, Ritchie M, Siemann E (1997) The influence of functional diversity and composition on ecosystem processes. Science 277, 13001302.

Tilman D, Reich PB, Knops J, Wedin D, Mielke T, Lehman C (2001) Diversity and productivity in a long-term grassland experiment. Science 294, 843-845.

Tilman D, Wedin D, Knops J (1996) Productivity and sustainability influenced by biodiversity in grassland ecosystems. Nature 379, 718-720.

Trnka M, Olesen JE, Kersebaum KC, Skjelvag AO, Eitzinger J, Seguin B, Peltonen-Sainio P, Rotter R, Iglesias A, Orlandini S, Dubrovsky M, Hlavinka P, Balek J, Eckersten H, Cloppet E, Calanca P, Gobin A, Vucetic V, Nejedlik P, Kumar S, Lalic B, Mestre A, Rossi F, Kozyra J, Alexandrov V, Semeradova D, Zalud Z (2011) Agroclimatic conditions in Europe under climate change. Global Change Biology 17, 2298-2318.

Van Peer L, Nijs I, Reheul D, De Cauwer B (2004) Species richness and susceptibility to heat and drought extremes in synthesized grassland ecosystems: compositional vs physiological effects. Functional Ecology 18, 769-778.

van Ruijven J, Berendse F (2010) Diversity enhances community recovery, but not resistance, after drought. Journal of Ecology 98, 81-86.

Vandermeer J (1989) 'The ecology of intercropping.' (Cambridge University Press: Cambridge)

Verheyen K, Bulteel H, Palmborg C, Olivie B, Nijs I, Raes D, Muys B (2008) Can complementarity in water use help to explain diversity-productivity relationships in experimental grassland plots? Oecologia 156, 351-361.

Vicca S, Gilgen AK, Serrano MC, Dreesen FE, Dukes JS, Estiarte M, Gray SB, Guidolotti G, Hoeppner SS, Leakey ADB, Ogaya R, Ort DR, Ostrogovic MZ, Rambal S, Sardans J, Schmitt M, Siebers M, van der Linden L, van Straaten O, Granier A (2012) Urgent need for a common metric to make precipitation manipulation experiments comparable. New Phytologist 195, 518-522.

Vicente-Serrano SM, Beguería S, Lorenzo-Lacruz J, Camarero JJ, López-Moreno JI, Azorin-Molina C, Revuelto J, Morán-Tejeda E, Sanchez-Lorenzo A (2012) Performance of drought indices for ecological, agricultural, and hydrological applications. Earth Interactions 16, 1-27.

Violle C, Enquist BJ, McGill BJ, Jiang L, Albert CH, Hulshof C, Jung V, Messier J (2012) The return of the variance: intraspecific variability in community ecology. Trends in Ecology \& Evolution 27, 244-252.

Violle C, Garnier E, Lecoeur J, Roumet C, Podeur C, 
Blanchard A, Navas ML (2009) Competition, traits and resource depletion in plant communities. Oecologia 160, 747-755.

Volaire F (1995) Growth, carbohydrate reserves and drought survival strategies of contrasting Dactylis glomerata populations in a Mediterranean environment. Journal of Applied Ecology 32, 56-66.

Volaire F, Lelievre F (1997) Production, persistence, and water-soluble carbohydrate accumulation in 21 contrasting populations of Dactylis glomerata L. subjected to severe drought in the south of France. Australian Journal of Agricultural Research 48, 933-944.

Volaire F, Lelievre F (2001) Drought survival in Dactylis glomerata and Festuca arundinacea under similar rooting conditions in tubes. Plant \& Soil 229, 225-234.

Volaire F, Norton M (2006) Summer dormancy in perennial temperate grasses. Annals of Botany 98, 927-933.

Volaire F, Norton M, Lelièvre F (2009) Summer drought survival strategies and sustainability of perennial temperate forage grasses in Mediterranean areas. Crop Science 49, 2386-2392.

Volaire F, Norton MR, Norton GM, Lelièvre F (2005) Seasonal patterns of growth, dehydrins and water-soluble carbohydrates in genotypes of Dactylis glomerata varying in summer dormancy. Annals of Botany 95, 981-990.

Volaire F, Thomas H, Bertagne N, Bourgeois E, Gautier MF, Lelièvre F (1998a) Survival and recovery of perennial of perennial forage grasses under prolonged Mediterranean drought: water status, solute accumulation, abscisic acid concentration and accumulation of dehydrin transcripts in bases of immature leaves. New Phytologist 140, 451-460.

Volaire F, Thomas H, Lelièvre F (1998b) Survival and recovery drought: growth, death, water relations and solute content in herbage and stubble. New Phytologist 140, 439-449.

Wasson AP, Richards RA, Chatrath R, Misra SC, Prasad SVS, Rebetzke GJ, Kirkegaard JA, Christopher J, Watt M (2012) Traits and selection strategies to improve root systems and water uptake in water-limited wheat crops. Journal of Experimental Botany 63, 3485-3498.

Weiher E, Freund D, Bunton T, Stefanski A, Lee T, Bentivenga S (2011) Advances, challenges and a developing synthesis of ecological community assembly theory. Philosophical Transactions of the Royal Society B-Biological Sciences 366, 2403-2413.

Weiher E, Keddy PA (1995) The assembly of experimental wetland plant-communities. Oikos 73, 323-335.

West CP, Oosterhuis DM, Wullschleger SD (1990) Osmotic adjustment in tissues of tall fescue in response to water deficit. Environmental and Experimental Botany 30, 149156.

White TA, Snow VO (2012) A modelling analysis to identify plant traits for enhanced water-use efficiency of pasture. Crop \& Pasture Science 63, 63-76.

Yang H, Auerswald K, Bai YF, Han XG (2011) Complementarity in water sources among dominant species in typical steppe ecosystems of Inner Mongolia, China. Plant and Soil 340, 303-313. 